\title{
O BRASIL ENTRE O FUTURO E O FUTURO
}

\section{José Maurício Domingues}

\section{Resumo}

Neste texto o autor procura analisar processos políticos que culminaram na atual configuração política do país. Ao longo de sua discussão, ele reflete sobre eventos, posturas, partidos e narrativas a partir das quais o país é pensado e a política, posta em prática.

Palavras-Chave: Democracia. Brasil. Política. Neoliberalismo.

O Brasil nos últimos anos passou por um processo político extremamente dinâmico e conturbado, desde as manifestações de 2013 até a eleição de Jair Bolsonaro para a Presidência da República. Após mais de uma década de governo do Partido dos Trabalhadores e o impeachment de Dilma Rousseff, as mudanças foram tremendas. De um país cuja democracia parecia estar se consolidando e em que a esquerda tinha presença significativa, senão dominante, ao menos no sentido de dirigir a conjuntura, passamos a uma situação em que a extrema-direita tem a iniciativa e os militares voltaram à linha de frente da política.

Muito disso tem a ver com os descaminhos da esquerda. Somente muita cegueira autoinflingida pode bloquear o reconhecimento dos erros do PT, do desastre da ilusão quanto ao poder ilimitado do ex-presidente Luiz Inácio Lula da Silva, o envolvimento com esquemas massivos de corrupção, da responsabilidade na pior crise econômica do Brasil moderno tal qual em larga medida provocada por Rousseff. É de difícil sustentação ademais a tese de que grandes forças se juntaram para impedir os modestos avanços na diminuição da pobreza e aberturas de vias de ascensão social para parcelas das classes populares. É preciso efetivamente mergulhar numa visão crítica da trajetória do PT e dos resultados do "lulismo" (falar 
de "legado" a esta altura soa como algo de mal gosto). Analisei isto em outras ocasiões (Domingues, 2015 e 2017). O consequencialismo - isto é, a ideia de que os fins justificam os meios - descambou para uma falta total de medida e benefícios pessoais.

No entanto, há processos mais profundos que talvez tenhamos que avaliar melhor. Nenhum deles levava necessariamente à ascensão fulminante da extremadireita, o que só ocorreu devido à repetição ad nauseam dos erros anteriormente cometidos - e que, ao que parece, se quer continuar a cometer.

Obviamente, a questão da dita "estrutura social" conta muito. O Brasil perdeu em grande medida sua classe operária e hoje possui um enorme contingente de trabalhadores assalariados na área de serviços em condições de trabalho e vida extremamente precárias. Os movimentos que tinham seu eixo no sindicalismo burocratizado e acomodado às tradicionais estruturas sindicais, ademais - se encontram sem reação. O agronegócio, com sua capacidade de controle de largas faixas da população, diretamente e ideologicamente, assim como a mineração se tornaram esteios da economia nacional e de sua política, ao passo que os movimentos rurais em grande medida se desmobilizaram. Um embate social fruto da pluralização das identidades, ressurgência do feminismo e afirmação das diferenças se choca contra um esforço nostálgico na direção, impossível, de girar a roda da história para trás. Forças políticas importantes, no empresariado mas também nos grupos políticos dominantes resolveram abraçar de maneira mais direta o neoliberalismo e fechar de vez um capítulo da modernização do país entre os anos 1930 e a Constituição de 1988. Por outro lado, a desconfiança com o sistema político, uma ânsia por participação e a demanda por mais democracia - ainda que 
desaguando no voto da extrema-direita para muitos - é visível e permeia a sociedade brasileira.

Isso tudo vem ocorrendo, porém, em uma situação em que pouco importava e importa um processo de educação nacional e de elevação cultural do país (Domingues, 2018). Abriu-se assim espaço para que argumentos de uma simplificação extrema pudessem ser vendidos à população, no estilo que a extremadireita internacionalmente vem desdobrando em todos os países. Nem a esquerda nem a direita se preocupam há tempos - ao contrário - com isso, desqualificando na prática e encurtando os espaços para que um debate nacional adequado e robusto pudesse ter lugar. Não por acaso aos intelectuais se devota, na esquerda, desprezo, a menos que sirvam como legitimadores de absurdas linhas partidárias, ao passo que à direita o que se assiste é uma inqualificável falsificação do pensamento (do que a esquerda, incluindo oportunistas e adventícios, infelizmente tampouco está isenta, ainda que em grau muito mais leve).

Um longo ciclo de "modernização conservadora" terminou nos anos 1980. Ele se desdobrou num processo social e político de democratização. Um ciclo relativamente longo, que durou dos anos 1970 aos 2000 se esgotou, com uma brutal derrota da esquerda. O centro tampouco vai bem, embora tenha agora a chance de se reestruturar longe do fisiologismo e do neoliberalismo que caracterizou nas últimas as suas diversas vertentes. Um novo ciclo, sob hegemonia da extremadireita, se abre, de contornos, dinâmica e futuro ainda obscuros e imprevisíveis. Dada a história do país e os desejos confessos dos novos governantes, ele terá caráter neoliberal e provavelmente bastante repressivo. Ou a esquerda e a centroesquerda se reinventam, ou os intelectuais reinventam o Brasil e seu futuro, ou essa é tendência que será difícil reverter. Na verdade, foi toda uma ideia de país que se 
esgotou - o futebol, o samba e alegria, as miscigenação e a diversidade geográfica, bem como a ideia do desenvolvimento que nos levaria à indústria e ao "primeiromundo", mantendo supostamente nossa exuberância natural infinita, com uma fisionomia própria e exclusiva, já não se sustentam, mas o que se apresenta como alternativa tampouco parece robusta e crível no longo prazo. Isso não quer dizer que não possa, de maneira amorfa, prevalecer, combinando alinhamento com o "ocidente", violência, cristianismo evangélico e conservador nos costumes e na educação, autoritarismo político e jurídico.

Observei em 2013 (primeira edição de Domingues, 2015) que a história do Brasil terminara e que uma nova história, muito breve e marcada pelos governos do PT, também chegava rapidamente ao fim. O que estava em questão era uma "novíssima" história do Brasil. Era possível ter a esperança de que as massivas manifestações de 2013 levassem a mais democracia, a menos oligarquia no sistema democrático liberal sob o qual vivíamos (e ainda vivemos, apesar de prováveis mudanças em curso, que não necessariamente significarão uma mudança de regime, conquanto decerto venha a desdemocratizá-lo). Isso representaria uma novíssima história progressista para o país. Nem se percebeu a mudança de era (muitos seguiram opondo o passado ao futuro, quando estávamos de fato àquela altura entre o presente e o futuro, ou seja, em outra temporalidade já), nem se preparou a esquerda para relançar seu projeto: seguiu-se fazendo recurso à oposição entre pobres e ricos, os quais no entanto nunca foram de fato atingidos, em lugar de propor um projeto mais inclusivo e mais criativo.

Ainda é tempo de fazê-lo. Resta saber se seremos capazes de enfrentar os mortos (e os vivos) que oprimem nossos cérebros e ações, do contrário, o futuro será de forças cujo horizonte conhecemos e cujos passos podem ser violentos e até 
mesmo imprevisíveis. Não se retorna ao passado: estamos entre dois futuros, que se decidem no presente de curto e médio prazo. Saímos em desvantagem. É preciso coragem nesta hora difícil, para criticar assim como para mudar, com a urgência que as mudanças de ciclo e de época exigem.

\section{Referências}

Domingues, José Maurício (2015) O Brasil entre o presente e o futuro. Conjuntura interna e inserção internacional (Rio de Janeiro: Mauad, 2a․ edição).

Domingues, José Maurício (2017) Esquerda. Crise e futuro (Rio de Janeiro: Mauad).

Domingues, José Maurício (2018) "Um novo Brasil, uma nova esquerda”, maisdeum, vol. 2 